\title{
RHEUMATOID NODULES
}

\section{A STUDY IN THEIR PATHOGENESIS AND THE EFFECTS OF CORTISONE AND ACTH}

\author{
BY \\ T. E. HUNT and A. J. BLANCHARD \\ Sunnybrook Hospital, Toronto, Canada
}

The dramatic remissions occurring in rheumatoid arthritis during the administration of cortisone or ACTH are now familiar observations. In addition to the volume of clinical and biochemical data already collected, there have been reports describing alterations in the pathological changes of the joint lesions with the use of these drugs. When one of our first cases to receive cortisone showed a rapid disappearance of a rheumatoid nodule over one knee, we became interested in studying the changes produced by hormone administration in these remarkable lesions. Six patients with multiple subcutaneous rheumatoid nodules were given either ACTH or cortisone and detailed observations were made of the effects upon this particular feature of their disease.

This paper presents the clinical and pathological findings which have been of interest; it refers only to the subcutaneous nodules of rheumatoid arthritis.

\section{The Rheumatoid Nodule}

The clinical and histopathological features of rheumatoid nodules show definite diagnostic patterns. The nodules are tender, subcutaneous masses, appearing most frequently over the posterior aspects of the forearms. They may be present also about the hands, neck, buttocks, knees, ankles, and feet. They vary from a few millimetres to several centimetres in diameter, and may be freely moveable, or fixed to the skin or to the underlying muscle or periosteum. The larger nodules are frequently composed of a number of smaller ones which have coalesced, and fluctuation may be demonstrated over them.

The aetiology of these lesions is unknown. Not all patients with rheumatoid arthritis develop them, and they have not been described in cases of ankylosing spondylitis of the Marie-Strümpell type. Most authorities agree, however, that trauma plays a very important aetiological role in nodule production, as witnessed by the frequent occurrence of the lesions on the back of the forearms where they rest on the arms of the chair. The influence of trauma was well demonstrated in a patient seen recently, who developed rheumatoid nodules on the right thumb the day after purchasing a new cigarette lighter; the next day he switched the lighter to the other hand and developed a transient nodule in the left thumb. 
The histological characteristics of the rheumatoid nodule have been fully described by Klinge (1933), Collins (1937), and Bennett and others (1940), and are considered to be pathognomonic. There are three distinct features:

(i) a central zone of necrosis and fibrinoid alteration;

(ii) an intermediate zone characterized by palisading of histiocytes and young fibroblasts, together with infiltration of small round cells;

(iii) an outer zone composed of fibrous tissue in which there are numerous blood vessels showing various types of alteration (Fig. 1).

In order to understand more fully the changes brought about by ACTH and cortisone, an initial attempt was made to ascertain the detailed pathogenesis of these lesions. For this purpose, a number of specimens were obtained from the patients prior to hormone administration, and several others were taken from the surgical pathology files. Paraffin sections, stained with haematoxylin and eosin, Masson's trichrome, toluidine blue, and the periodic acid-leucofuchsin method of McManus, were studied. All specimens were fixed in 95 per cent. ethyl alcohol.

Although there has been considerable controversy in the past concerning the initial lesions, we would agree with Klinge (1933) that the first changes consist of alterations in the amorphous ground substance of the subcutaneous connective tissue. In the haematoxylin and eosin sections, this is characterized by a mucoid oedematous appearance. There is a spreading apart of the collagen fibres and a fraying of individual fibres apparently due to changes in the ground substance binding together their component fibrils (Fig. 2). Further study using

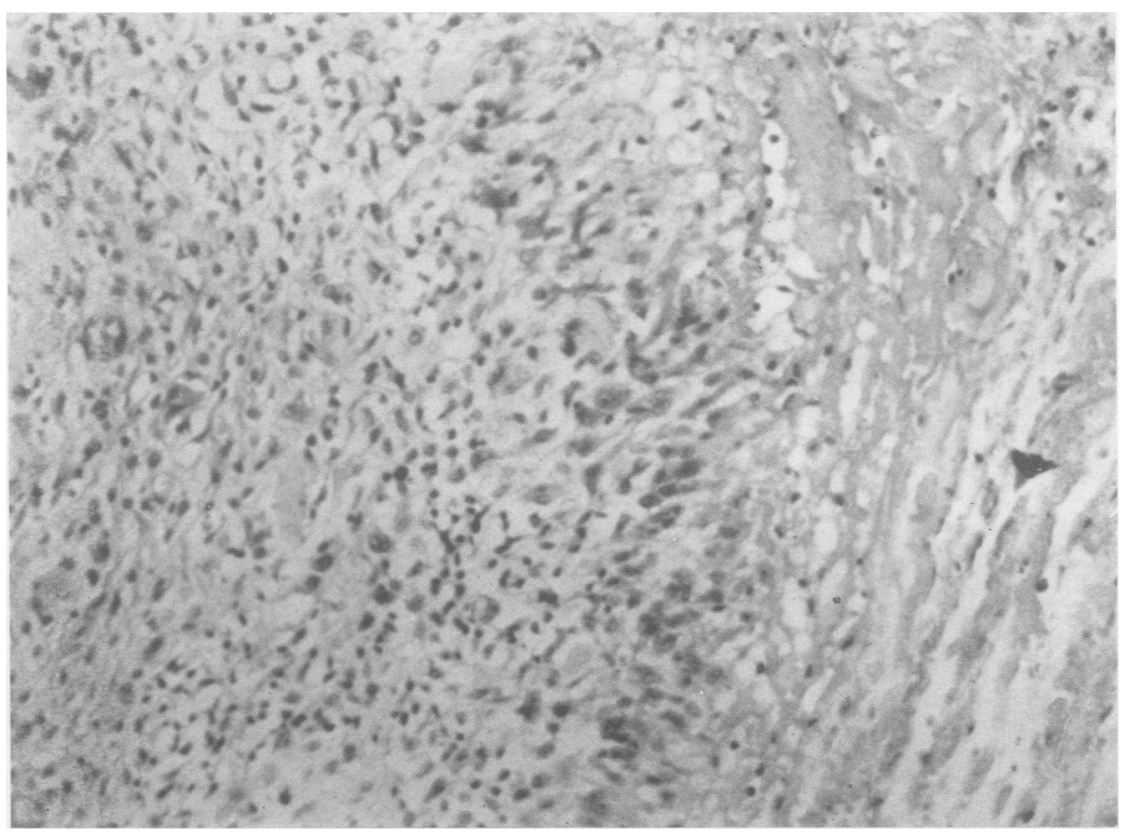

FIG. 1.-Haematoxylin and eosin section demonstrating characteristic features of rheumatoid nodule. Right to left: central zone of fibrinoid alteration and necrosis, palisading of mesenchymal cells, peripheral inflammatory reaction. 
toluidine blue stain, however, reveals that the ground substance has not disappeared but has undergone certain alterations which cause the dye to stain metachromatically (Fig. 3). Spatially related to these changes, there appears the fibrillar

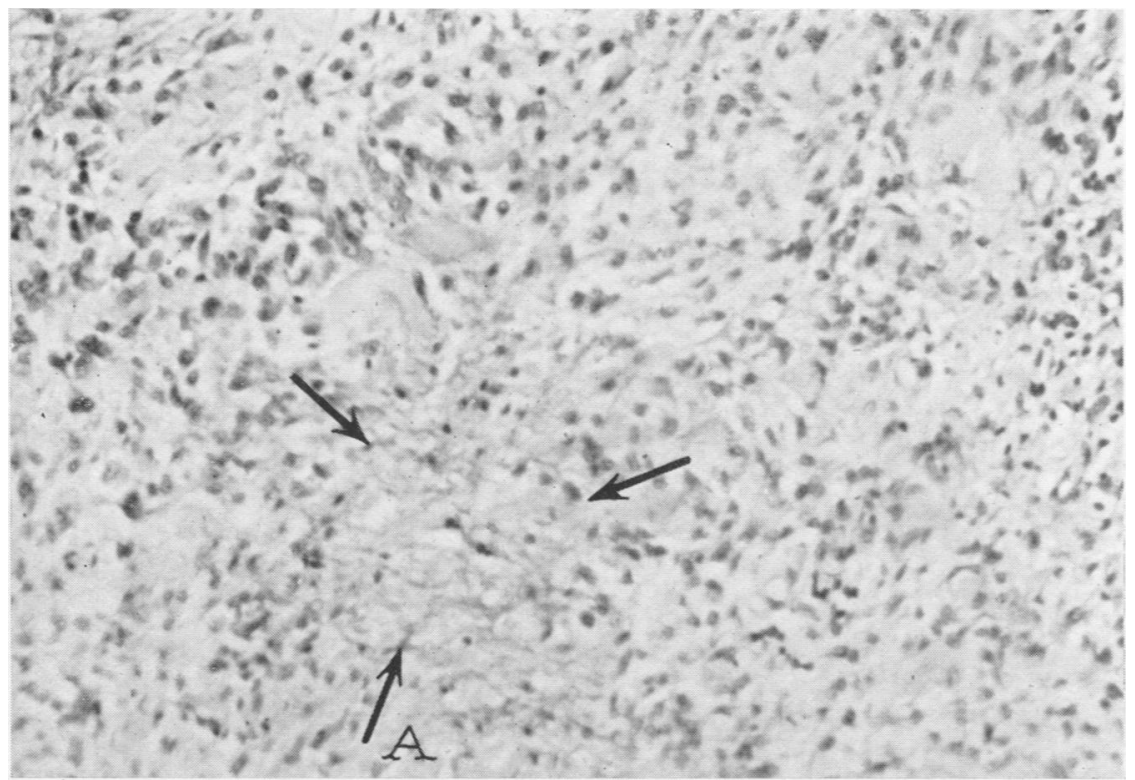

FIG. 2.-Haematoxylin and eosin section demonstrating initial early lesion with area of mucinous oedema and fibrinoid alteration (A) surrounded by granulomatous reaction.

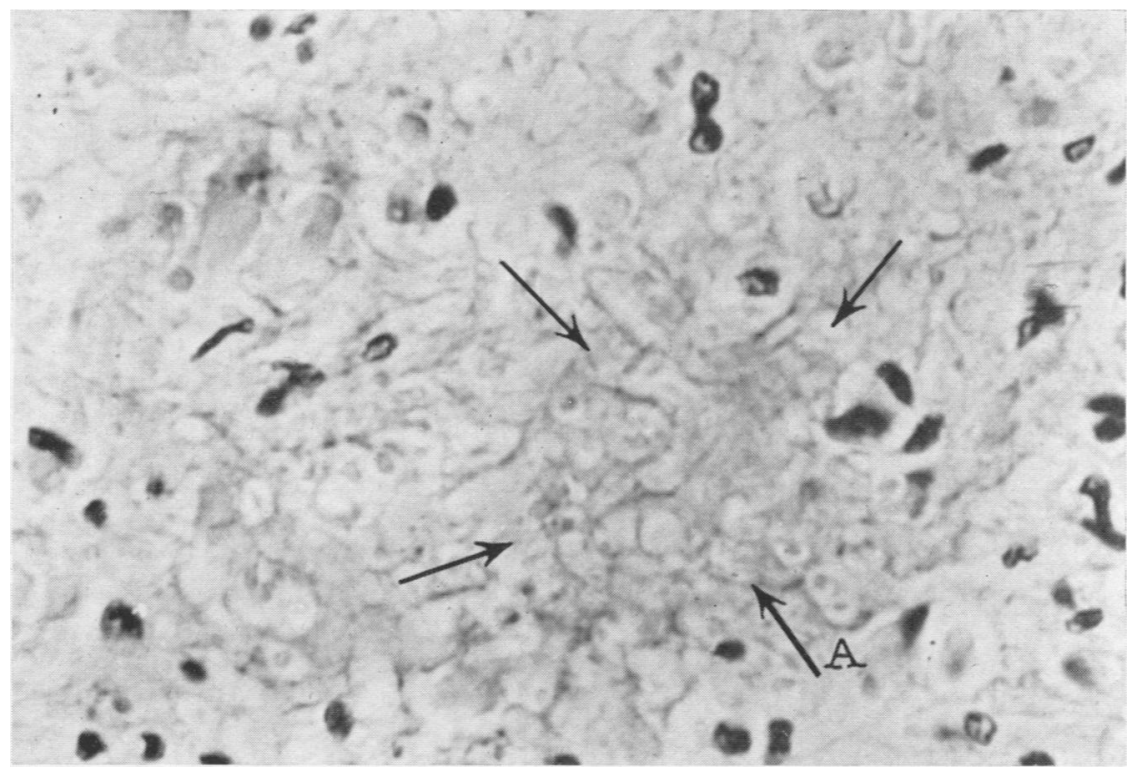

FIG. 3.-Serial section to that in Fig. 2 stained with toluidine blue. The dark material within the arrows represents metachromatic staining of altered ground substance. 
eosinophilic substance, fibrinoid. This is the fundamental lesion described in all the so-called collagen diseases.

The present concept of the mode of production of these lesions has been greatly clarified by the recent histochemical work of Altshuler and Angevine (1949). The intercellular amorphous ground substance of normal connective tissue is mucinous in nature, and is composed, partly at least, of acid mucopolysaccharidesmainly hyaluronic acid and chondroitin sulphuric acid. In the collagen diseases, because of the action of various noxious agents, or possibly as a result of an altered immunity mechanism (Aergerter and Long, 1950), it is felt that there is an increased accumulation, or alteration of the mucopolysaccharides, and also a change in the colloidal nature of the ground substance, which becomes less viscous and more oedematous. This increase in acid mucopolysaccharides is demonstrated by the pink or metachromatic staining with toluidine blue dye. It is felt that, while this process is occurring, an alkaline protein, perhaps derived from necrosis of the surrounding tissue, or from the interaction of the tissue with the damaging agent, produces a co-precipitate with the acid mucopolysaccharides, thus forming fibrinoid. As a result of this profound alteration in ground substance, the diffusion of nutrient elements and the elimination of cellular catabolytes may be interfered with, and necrosis of cells takes place.

Associated with these early changes in the rheumatoid nodules, is a proliferative, and to a lesser extent exudative, inflammatory reaction in the surrounding tissues. As the lesion progresses, a further inflammatory change takes place in the region of increasing fibrinoid alteration and cellular necrosis; this consists of a granulomatous proliferation of local fibroblasts and histiocytes to form a palisaded zone about the central area of necrosis-as if in an attempt to wall off the lesion. However, progressive alteration in the intercellular ground substance lying between these newly-formed proliferating cells causes many of the cells to become damaged, die, and become absorbed into the ever-expanding central area. As the process extends, collagen fibres in the area then seem to undergo a non-specific fragmentation, and the fragments can be seen lying free in the central area. The necrotic material in these central areas undergoes liquefaction, and bursa-like cavities may be produced. Often polymorphonuclear leucocytes infiltrate into the cavities, and sometimes, in old, longstanding lesions, large deposits of cholesterol crystals may be seen. In the peripheral zone, in addition to diffuse cellular infiltration, perivascular accumulations of chronic inflammatory cells frequently occur. New blood vessels develop, and marked changes may occur in the vessels themselves, including thrombosis, fibrinoid alteration and necrosis of the vessel walls, and sclerosis.

Thus the final picture is produced: a central zone of fibrinoid alteration, necrosis, and liquefaction, with an ever-retreating surrounding wall of palisaded fibroblasts and histiocytes associated with a chronic inflammatory reaction. Some of the larger, older nodules may show several, smaller, satellite areas in all stages of development. A not uncommon picture is the final coalescence of a number of nodules, some with huge bursa-like central cavities. 


\section{Effects of ACTH and Cortisone upon Rheumatoid Nodules}

Our observations of the effects of cortisone and ACTH on rheumatoid nodules, agree with those of others who have commented specifically on this subject. Various observers have reported a considerable decrease in the size of the nodules, but not their complete disappearance. No pathological details are available in the literature to date.

Material.-Four of the six patients in this study had well-established severe rheumatoid disease, characterized by multiple severe deformities of peripheral joints, a number of subcutaneous nodules, very high sedimentation rates, and elevated serum globulins. They had not responded to treatment and had been hospitalized for long periods.

The other two cases had much milder disease, without marked deformities, and lower sedimentation rates.

Therapy.-The two milder cases received ACTH intramuscularly and responded satisfactorily to daily doses of 40 and $80 \mathrm{mg}$. respectively.

Of the four severe cases, two were given cortisone orally, and the other two ACTH intramuscularly. To produce and maintain adequate remissions in these more severe cases, larger dosages of the hormones were required-as much as $200 \mathrm{mg}$. cortisone or $160 \mathrm{mg}$. ACTH per day, for weeks at a time. No significant side-effects were observed.

The nodules were removed at varying times during hormone administration, for comparison with specimens taken previously, and other specimens, obtained during the relapse period which followed withdrawal of the drugs, have also been studied.

Results.-The clinical and histopathological changes observed followed a constant pattern; hence a composite description of our results is given rather than an analysis of individual cases.

Clinical.-The patients experienced a dramatic relief from pain and stiffness, as well as a decrease in all the objective signs of joint disease. The sedimentation rates fell with adequate doses of the hormones, but this occurred very slowly in the severe cases, and a plateau appeared to be reached after which there was no further decline. This feature differed from our previous observations of the effects of the hormones on rheumatoid arthritis without nodules, where rapid falls in sedimentation rates to normal were the rule even in the presence of very advanced active disease. The nodules rapidly lost their tenderness and within a few days appeared to be much softer in consistency. On several occasions, a lesion previously considered to be a large single mass could now be felt to be composed of a number of smaller nodules. After 5 to 10 days they began to decrease in size, but, except for one very small nodule in one patient who received ACTH, none disappeared completely (Figs 4 and 5, overleaf). A plateau seemed to be reached after 3 to 4 weeks, and no further changes in the nodules were apparent upon clinical examination thereafter. A rapid increase in the size and tenderness of the nodules followed withdrawal of the drugs.

Histological.-These changes were of considerable interest. Specimens taken only 5 days after starting hormone administration showed almost complete disappearance of the oedema, and of the metachromatic properties of the ground substance at the edges of the central zones. In one case, some metachromasia was still present after 22 days on ACTH, but this was only in the centre of the 


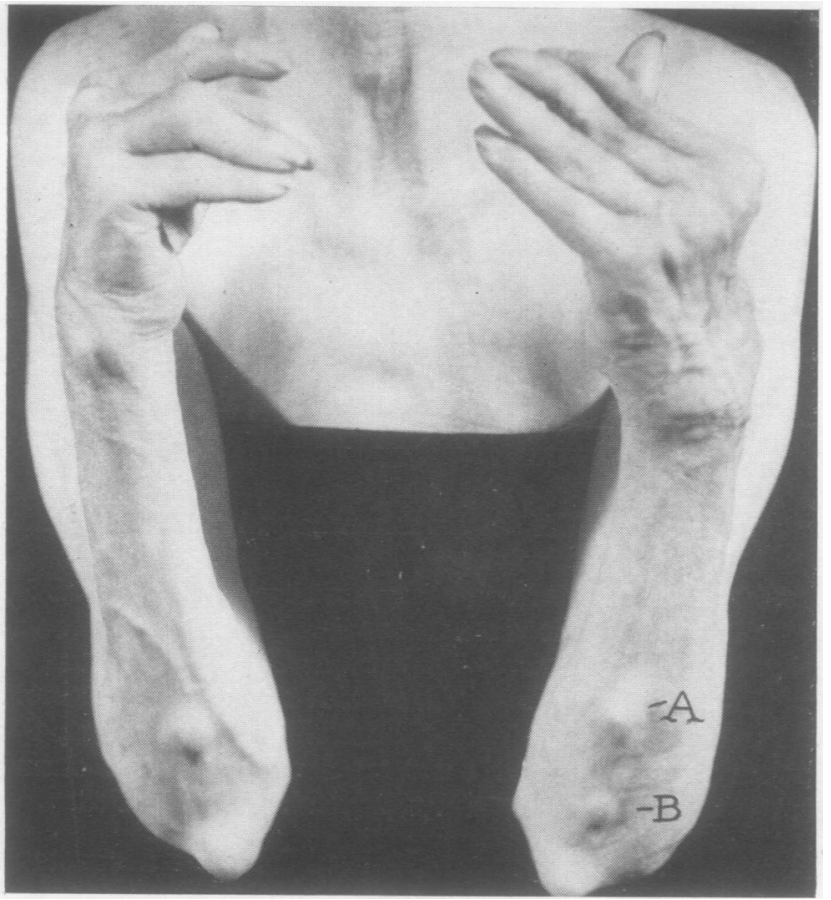

FIG. 4.-Patient J.D., male, aged 59, before ACTH. Compare nodules at $\mathrm{A}$ and B with Fig. 5.

FIG. 5.-Same patient as in Fig. 4 after 21 days on ACTH. Nodule $A$ has greatly decreased and $B$ has completely disappeared.

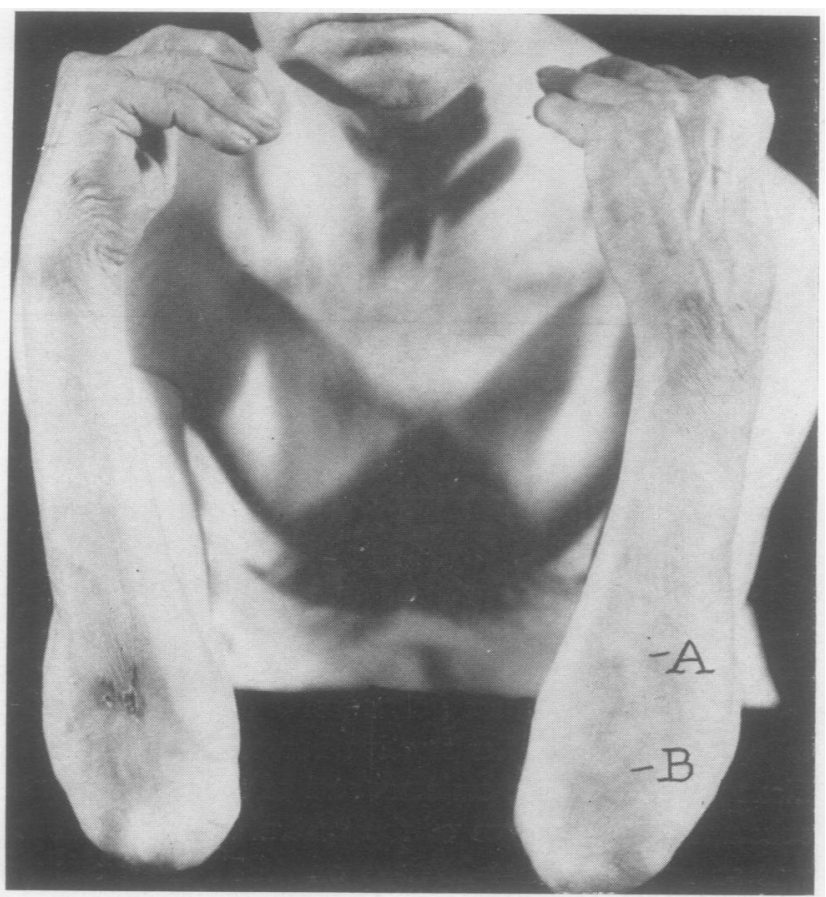




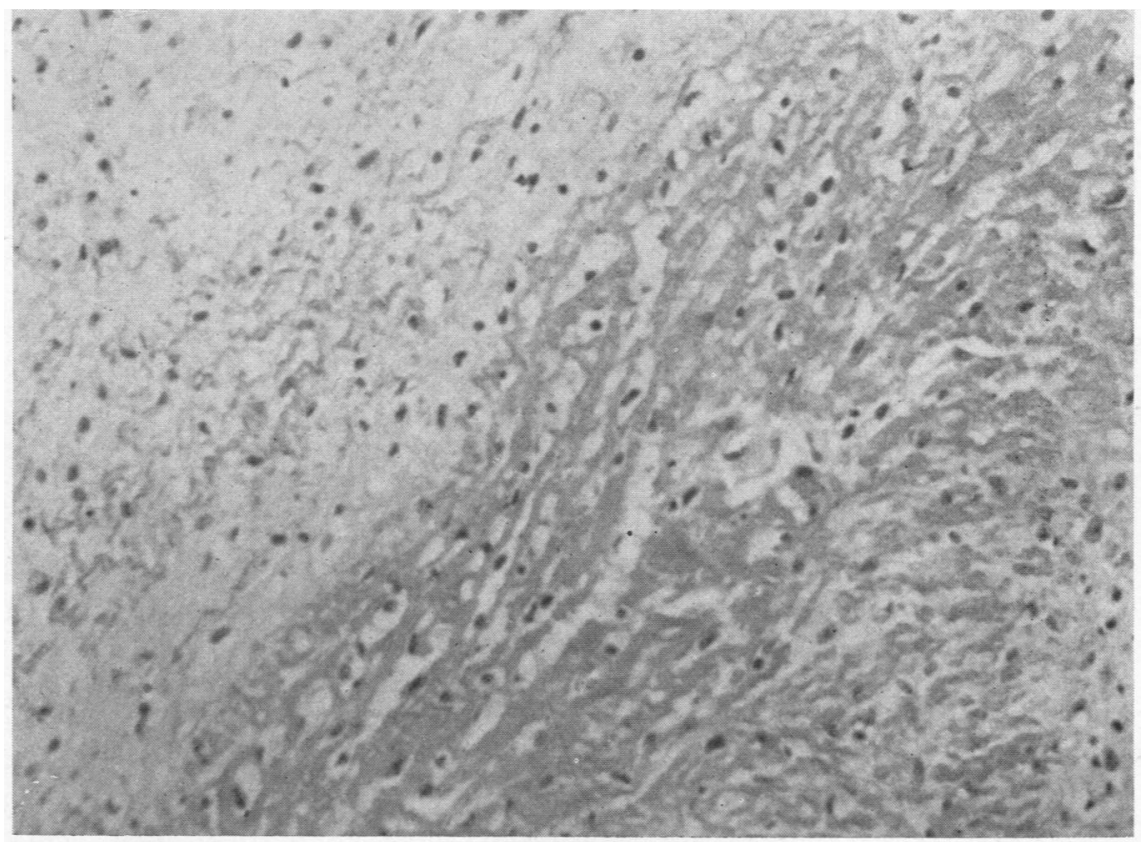

Fig. 6.-Haematoxylin and eosin section of nodule after 5 days on cortisone. Right to left: persistence of fibrinoid alteration and necrosis, complete disappearance of palisading, marked reduction in peripheral inflammatory reaction.

Serial section stained with toluidine blue showed absence of metachromasia.

necrotic material, and did not appear to be related to the fibrinoid. Associated with this there was a striking reduction in the surrounding reaction. The palisading disappeared completely and there was a marked decrease in the inflammatory reaction. Fibrinoid alteration was still present centrally at first, and many degenerating nuclei were intermingled with this material (Fig. 6); these possibly represented cells from the disintegrated palisaded zone. In subsequent specimens even the fibrinoid material had disappeared, and in some instances the central zone was composed merely of old necrotic material and clumps of fragmented collagen fibres (Fig. 7). There was no evidence of destruction of pre-existing fibrous tissue. No acute degenerative abnormalities of the blood vessels were observed in specimens taken during hormone administration.

In the sections of specimens removed after relapse had occurred, striking amounts of metachromatic and fibrinoid material had recurred. Almost the entire specimen would be composed of fibrinoid with very little surrounding reaction and only a beginning of palisading. These changes appeared to be almost fulminating in intensity (Fig. 8).

\section{Comment}

The changes demonstrated after hormone administration consist chiefly in alterations of the intercellular substances to produce a more normal state, and in 
Fig. 7.-Haematoxylin and eosin section of nodule after 14 days on cortisone. Right to left: disappearance of fibrinoid alteration, absence of palisading, absence of peripheral inflammatory reaction. Central zone (on right) shows only amorphous, necrotic, granular material as yet unabsorbed.

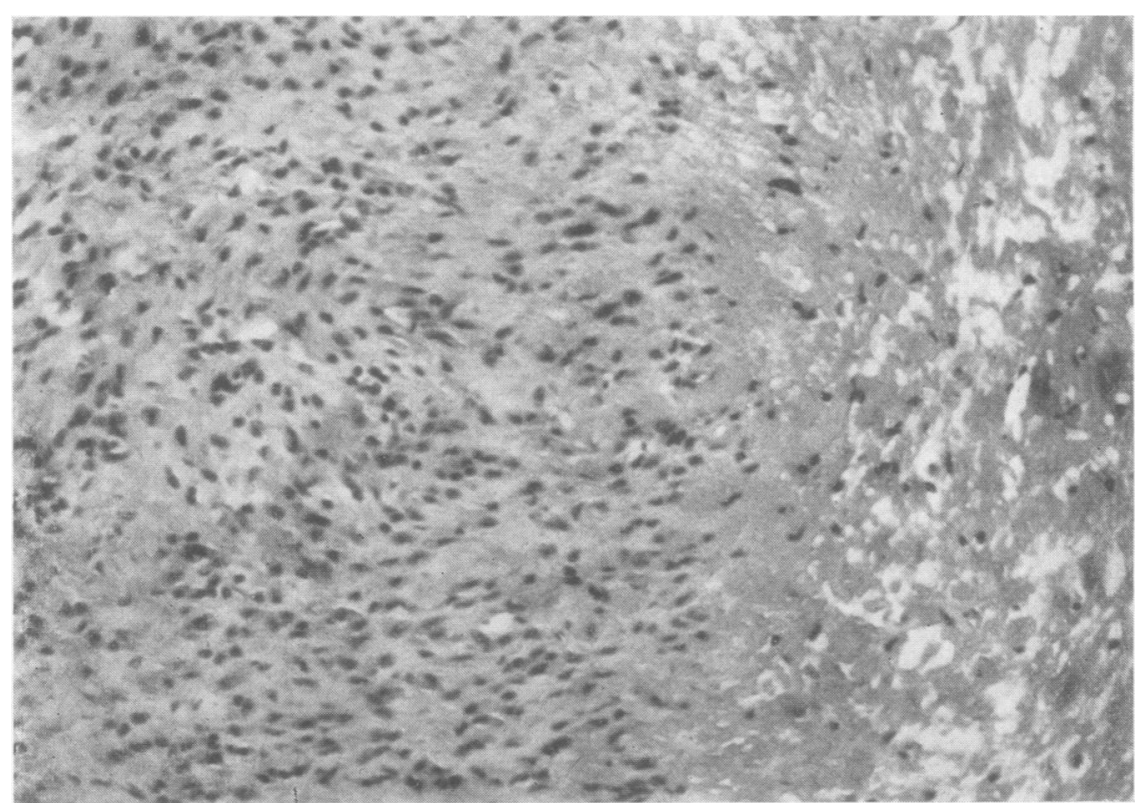

음

훌

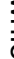

음

윽

Fig. 8.-Haematoxylin and eosin section of enlarging nodule 5 days after cortisone withdrawal, showing reappearance of fibrinoid (right), but little palisading or inflammatory response so far. Serial section stained with toluidine blue demonstrated reappearance of metachromasia.

a reduction in the proliferative reaction of the intermediate zone in the nodules. The decreased oedema and the reduction in the granulomatous reactions probably 
account for the lesions being softer and smaller upon clinical examination. The changes in the ground substance recall the changes demonstrable in vitro by the treatment with hyaluronidase of sections showing metachromasia. There is also a similarity to the appearance of granulation tissue in scurvy. In both instances, metachromasia to toluidine blue is absent.

In the case of scorbutic granulation tissue, administration of vitamin $\mathrm{C}$ has been shown by Penney and Balfour (1949) to cause the appearance within 12 hours of metachromasia in ground substance with subsequent production of normal granulation tissue. This indicates that vitamin $\mathrm{C}$ is necessary for the development of metachromasia in granulation tissues. The thought arises that the changes produced by cortisone or ACTH might be the result of local ascorbic acid deficiency due to hormone administration. No positive opinion can yet be given, but we may refer to the work of Plotz and others (1950), who were unable to block the action of the hormones in their patients by massive doses of vitamin C.

A second possibility which suggests itself is that the hormones may produce a local hyaluronidase-like effect, either directly on the ground substance or by stimulation of the connective tissue cells to produce such an effect. However, Opsahl (1949) has shown that both cortisone and ACTH have an inhibitory effect on the spreading phenomenon induced by hyaluronidase. Hence it would not appear likely that the hormones act through local production of that enzyme.

A third possibility is that the hormones act directly on the connective tissue cells and intercellular substances, somehow protecting them from the action of the injurious agent, and that the chain of events in the ground substance leading to mucinous oedema and fibrinoid precipitation is accordingly inhibited.

Again, the hypothesis has been advanced that the administration of cortisone or ACTH results in a more normal antigen-antibody relationship, thus preventing the noxious influence associated with the altered immunity mechanism discussed by Aergerter and Long (1950). The striking reductions towards normal of certain elevated serum globulin fractions support this idea.

The striking decrease in the proliferative reaction within rheumatoid nodules during ACTH or cortisone administration recalls the observations of Plotz and others (1950) and of Spain and others (1950). These workers noted that the administration of these hormones delayed the appearance of connective tissue in a series of wounds in experimental animals.

In our cases, the hormones may directly inhibit the proliferation of the mesenchymal cells in the palisaded zone, or again, by the blocking or inhibition of the action of the noxious agent, they may remove the stimulus to proliferation. The rapid relapse with recurrence of nodule formation, indicates that the underlying aetiological agent was not eliminated, but that its action was temporarily suppressed.

\section{Summary}

(1) In six cases of active rheumatoid arthritis with subcutaneous nodules, the administration of ACTH or cortisone led to a definite softening and shrinkage of the nodules, but, except for one small nodule, the lesions did not disappear. 
(2) In four severe cases, the sedimentation rates fell very slowly and incompletely even with large doses of the hormones. This is of interest since in other rheumatoid patients, with disease of similar severity but without nodules, sedimentation rates rapidly fell to normal during the use of these hormones.

(3) The histological changes induced in the nodules consisted of:

(a) disappearance of the mucinous oedema of the ground substance and inhibition of fibrinoid alteration;

(b) striking reduction in the proliferation of mesenchymal cells in the zone surrounding the central areas of necrosis;

(c) no apparent effect on the peripheral zones of fibrous tissue.

(4) Possibilities regarding the mode of action of the hormones are discussed.

\section{REFERENCES}

Aegerter, E., and Long, J. (1950). Amer. J. Path., 26, 702.

Altshuler, C. H., and Angevine, D. M. (1949). Ibid., 25, 1061.

- - (1951). Ibid., 27, 141.

Bennett, G. A., Zeller, J. W., and Bauer, W. (1940). Arch. Path., Chicago, 30, 70.

Collins, D. H. (1937). J. Path. Bact., 45, 97.

Klinge, F. (1933). Ergebn. allg. Path. path. Anat., 27 (whole vol.).

Opsahl, J. C. (1949). Yale J. Biol. Med., 22, 115.

Penney, J. R., and Balfour, B. M. (1949). J. Path. Bact., 61, 171.

Plotz, C. M., Howes, E. L., Meyer, K., Blunt, J. W., Lattes, R., and Ragan, C. (1950). Amer. J. Path., 26, 709.

Spain, D. M., Molomut, N., and Haber, A. (1950). Ibid., 26, 710.

\section{Nodules Rhumatismaux: Étude des Effets de la Cortisone et de l'ACTH RÉSUMÉ}

(1) Dans six cas d'arthrite rhumatismale active avec présence de nodules souscutanés, l'administration de l'ACTH ou de la cortisone mena à un ramollissement notable et à la contraction des nodules mais, à l'exception d'un petit nodule, ces lésions ne disparurent pas.

(2) Dans quatre cas graves, la vitesse de la sédimentation ne diminuait que lentement et incomplètement, même avec de fortes doses de ces hormones. Ceci est d'un intérêt particulier par le fait que dans nos cas de rhumatisme de gravité similaire, mais sans présence de nodules, la sédimentation globulaire se ralentissait rapidement sous l'influence de ces hormones.

(3) Les altérations histologiques subies par ces nodules étaient les suivantes:

(a) disparition de l'oedème mucineux de la substance basale, et l'inhibition de la transformation fibrinoide;

(b) réduction frappante de la prolifération des cellules mésenchymateuses dans la zone entourant les surfaces centrales de nécrose;

(c) pas d'effet apparent sur les zones périphériques de tissu fibreux.

(4) On discute certaines possibilités concernant le mode d'action des hormones.

Nódulos Reumáticos: Estudio de los Efectos que sobre ellos ejercen la Cortisona y la ACTH Sumario

(1) En seis casos de artritis reumatoide activa con presencia de nódulos subcutáneos, la administración de la ACTH o de la cortisona condujo a un notable ablandamiento y contracción de los nódulos pero, con la excepción de un pequeño nódulo, estas lesiones no desaparecieron.

(2) En cuatro casos graves la velocidad de sedimentación eritrocitaria disminuyo muy lenta e incompletamente, aún con dosis fuertes de las hormonas. Esto presenta un interés particular ya que en nuestros casos de reumatismo de gravedad similar, pero sin presencia de nódulos, la sedimentación bajaba rápidamente bajo la influencia de estas hormonas.

(3) Los cambios histológicos inducidos en los nódulos fueron los siguientes:

(a) desaparición del edema mucinoso de la substancia basal, e inhibición de la transformación fibrinoide;

(b) reducción asombrosa en la proliferación de células mesenquimatosas en la zona periférica de las áreas centrales de necrosis;

(c) ausencia de efecto aparente en las zonas periféricas del tejido fibroso.

(4) Se discuten ciertas posibilidades respecto al modo de acción de estas hormonas. 